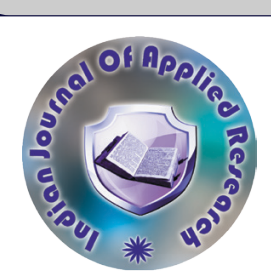

Physical Education

\title{
EFFECT OF COMBINED PRANAYAMA AND MEDITATION PRACTICES ON SELF CONFIDENCE AMONG HOCKEY PLAYERS
}

\section{Mrs. T. Priya \\ Prof. K. Muralirajan*}

Alagappa University College Of Physical Education, Alagappa University, Karaikudi, Tamilnadu, India

Alagappa University College Of Physical Education, Alagappa University, Karaikudi, Tamilnadu, India * Corresponding Author

ABSTRACT The purpose of the present study was to investigate the effect of combined pranayama and meditation practices on self confidence among hockey players. To achieve the purpose of the study thirty hockey players were selected from Karaikudi, Tamilnadu, India during the year 2019. The subject's age ranges from 14 to 17 years. The selected students were divided into two equal groups consists of 15 players each namely experimental group and control group. The experimental group underwent a combined pranayama and meditation practices programme for six weeks. The control group was not taking part in any training during the course of the study. Self confidence was taken as criterion variable in this study. The selected subjects were tested on Self confidence was measured through Vealy's trait sports confidence inventory (TSCI) assessment. Pre-test was taken before the training period and post- test was measured immediately after the six week training period. Statistical technique ' $t$ ' ratio was used to analyse the means of the pre-test and post test data of experimental group and control group. The results revealed that there was a significant difference found on the criterion variable. The difference is found due to combined pranayama and meditation practices given to the experimental group on Self confidence when compared to control group.

\section{KEYWORDS : Combined Pranayama And Meditation Practices, Self Confidence And't' Ratio}

\section{INTRODUCTION}

Today, sports have become a part and parcel of our culture. It is being influenced and does influence all our social institutions including education, economics, arts, politics, law, mass communication and even international diplomacy (Alaguraja, K. et.al, 2019) ${ }^{4}$. Yoga is universally benefiting all people of all ages. The study of Yoga is fascinating to those with a philosophical mind and is defined as the silencing of the mind's activities which lead to complete realization of the intrinsic nature of the Supreme Being (Alaguraja, K. et.al., 2017) ${ }^{1}$. In the sports world, physical education is the most essential aspect due to the fact physical schooling increases the performance and the effectiveness of the sports (Alaguraja, K. et.al., 2018)

Yoga is a system of exercises which helps the mind and body in order to achieve tranquillity and spiritual insight (Alaguraja, K. et.al, 2019) ${ }^{5}$. Make sure that when you practice yoga asanas, you don't just stretch the body because the mind has to be with the body. (Alaguraja, K. et.al, $2019)^{8}$. One can start practicing Yoga at any given moment of time and you may start with meditation or directly with pranayama without even doing the asanas (postures). (Alaguraja, K. et.al, 2019) ${ }^{3}$. Today's there is an escalating emphasis on appearing smarter, feeling etter and living longer. In order to achieve these ideals as, scientific evidence tells us that one of the keys is high fitness and exercises (Alaguraja, K. et.al, $2019)^{7}$. When consciousness is operating with the intellect and with all the senses, by making an individual think that he or she is awake and aware, but the mind is actually less receptive and more critical (Yoga, P. et. al., 2019) ${ }^{9}$

\section{RESEARCH METHODOLOGY}

\section{Selection of subjects}

The purpose of the study was to find out the effect of combined pranayama and meditation practices on self confidence among hockey players. To achieve this purpose of the study, thirty girl's hockey players were selected as subjects at random. The age of the subjects were ranged from 14 to 17 years.

\section{SELECTION OF VARIABLE}

\section{Dependent Variable}

- Combined pranayama and meditation practices

\section{Independent variable}

- Self confidence

\section{EXPERIMENTAL DESIGNAND IMPLEMENTATION}

The selected subjects were divided into two equal groups of fifteen subjects each, such as a combined pranayama and meditation practices group (Experimental Group) and control group. The experimental group underwent combined pranayama and meditation practices for five days per week for six weeks. Control group, which they did not undergo any special training programme apart from their regular physical activities as per their curriculum. The following psychological variable namely Self confidence was selected as criterion variable. All the subjects of two groups were tested on selected criterion variable Self confidence was measured through Vealy's trait sports confidence inventory (TSCI) assessment method at prior to and immediately after the training programme.

\section{STATISTICAL TECHNIQUE}

The't' test was used to analysis the significant differences, if any, difference between the groups respectively.

\section{LEVEL OF SIGNIFICANCE}

The 0.05 level of confidence was fixed to test the level of significance which was considered as an appropriate.

\section{ANALYSIS OF THE DATA}

The significance of the difference among the means of the experimental group was found out by pre-test. The data were analysed and dependent ' $t$ ' test was used with 0.05 levels as confidence.

TABLE I Analysis of t-ratio for the pre and post tests of experi mental and control group on Self confidence

(Scores counts in number)

\begin{tabular}{|c|c|c|c|c|c|}
\hline Variables & Group & \multicolumn{2}{|c|}{$\begin{array}{c}\text { Standard } \\
\text { Deviation }\end{array}$} & \multicolumn{2}{c|}{ Sd Error } \\
\cline { 3 - 6 } & & Pre & Post & Pre & Post \\
\hline Self confidence & Control Group & 8.15 & 8.25 & 2.10 & 2.13 \\
\cline { 2 - 6 } & $\begin{array}{c}\text { Experimental } \\
\text { Group }\end{array}$ & 10.37 & 9.67 & 2.67 & 2.49 \\
\hline
\end{tabular}

\section{TABLE II}

\begin{tabular}{|c|c|c|c|c|c|}
\hline Variables & Group & \multicolumn{2}{|c|}{ Mean } & \multirow{2}{*}{$\begin{array}{c}\text { Degree of } \\
\text { freedom }\end{array}$} & 't' ratio \\
\cline { 3 - 6 } & & Pre & Post & \\
\hline Self confidence & Control Group & 75.53 & 75.93 & 14 & 1.14 \\
\cline { 2 - 5 } & $\begin{array}{c}\text { Experimental } \\
\text { Group }\end{array}$ & 73.4 & 83.13 & 14 & $14.47^{*}$ \\
\hline
\end{tabular}

*Significance at 5 level of confidence.

The Table-I and II shows that the mean values of pre-test and post-test of the control group on Self confidence were 75.53 and 75.93 respectively. The obtained ' $t$ ' ratio was 1.14 , since the obtained ' $t$ ' ratio was less than the required table value of 2.14 for the significant at 0.05 level with 14 degrees of freedom it was found to be statistically 
insignificant. The mean values of pre-test and post-test of the experimental group on Self confidence were 73.4 and 83.13 respectively. The obtained ' $t$ ' ratio was $14.47 *$ since the obtained ' $t$ ' ratio was greater than the required table value of 2.14 for significance at 0.05 level with 14 degrees of freedom it was found to be statistically significant. The result of the study showed that there was a significant difference between control group and experimental group in Self confidence. It may be concluded from the result of the study that experimental group improved in Self confidence due to six weeks of combined pranayama and meditation practices.

Figure-1 Bar Diagram Showing the Pre and Post Mean Values of Experi mental and Control Group on Self confidence

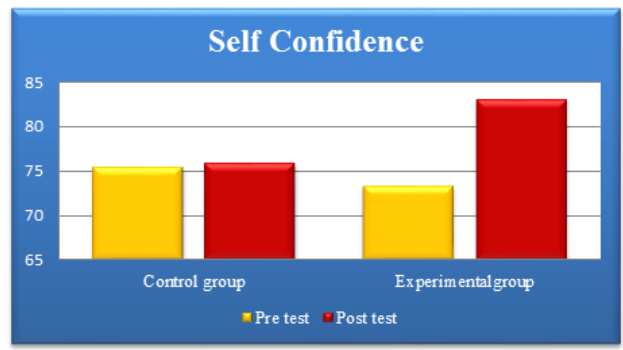

\section{DISCUSSIONS ON FINDINGS}

The result of the study indicates that the experimental group, namely combined pranayama and meditation practices group had significantly improved the selected dependent variable, namely Self confidence, when compared to the control group. It is also found that the improvement caused by combined pranayama and meditation practices when compared to the control group.

\section{CONCLUSION}

On the basis of the results obtained the following conclusions are drawn,

1. There was a significant difference between experimental and control group on Self confidence after the training period.

2. There was a significant improvement in Self confidence. However the improvement was in favor of experimental group due to six weeks of combined pranayama and meditation practices.

\section{REFERENCES}

1. Alaguraja, K., \& Yoga, P. (2017). Influence of yogasana practice on flexibility among obese adolescent school boys. International Journal of Yoga, Physiotherapy and Physical Education, 2(7), 70-71.

2. Alaguraja, K., \& Yoga, P. (2018). Effect of core stability training on dynamic strength among college male students. International Journal of Yogic, Human Movement and among college male students.
Sports Sciences, $3(2), 436-437$.

3. Alaguraja, K., \& Yoga, P. (2019). Effect of yogic practice on resting pulse rate among school students. Indian Journal of Applied Research, 9, (7), 17-18.

4. Alaguraja, K., Yoga, P., Balamuralikrishnan, R., \& Selvakumar, K. (2019). A scientific study on efficacy of yogic package on resting pulse rate among obese school students. Journal of Information and Computational Science, 9(8), 483-487.

5. Alaguraja, K., \& Yoga, P. (2019). Effect of yogic practice on resting pulse rate among school students. Indian Journal of Applied Research, 9, (7), 17-18.

6. Alaguraja, K., \& Yoga, P. (2019). Analyze of pranayama technique on physiological parameter among rural school students. Journal of Information and Computational parameter among rural
Science, $9(8), 545-550$.

7. Alaguraja, K., Yoga, P., James Rathinaraj, S., R., \& Selvakumar, K. (2019). A study on yoga intervention on maximal oxygen uptake among stress patient. Indian Journal of Applied Research, 9, (9), 38-39.

8. Alaguraja, K., \& Yoga, P. (2019). Effect of yogic practice on resting pulse rate among school students. Indian Journal of Applied Research, 9, (7), 17-18.

9. Yoga, P., Balamuralikrishnan, R., \& Alaguraja, K. (2019). Influence of cyclic meditation on selected physiological parameter. International Journal of Advanced Education and Research, 4(1), 17-18.

10. Jackson C. Healing ourselves, healing others: first in a series. Holistic Nursing Practice, 2004; 18(2): p. 67-81.

11. Strukic, P.J. Basic Physiology, New York: Spring Ervellong Inc. 1981; p.23.

12. Farhi D.,(2005). Bringing Yoga to Life: The everyday practice of Enlightened Living. Harper Collins Publisher, Australia

13. Sunil(2014). The importance of yoga in daily Life. https:/ www. Researchgate.net/publication/278673574, accessed. 2015, 2017. 